\title{
Religious Foundations of Group Identity in Prehistoric Europe: The Germanic Peoples
}

\begin{abstract}
Any reader of Heimskringla ("circle of the earth"), the history of the kings of Norway by the great 13 th century Icelandic writer Snorri Sturluson, will be struck by the enormous weight which the author attaches to religion. This refers both to Christianity and to pagan phenomena which preceded and even co-existed with it for some time. Snorri's work should, in my view, be ascribed a relatively high source value, if only because it is demonstrably based on older traditions either fixed in poetry or transmitted as oral prose. Oral tradition is of course not the topic of the present paper (cf. Buchholz 1980; Buchholz 1991), but the preservation of such traditions alone, many of which contain religious material, does indeed show that society or parts of it attached sufficient importance to such phenomena as to commit them to memory, parchment, runic signs or pictorial representation. The last scribe or "author" may of course have had considerable antiquarian interests, as is evident e.g. in some of the mythic poems of the Elder Edda, but such interests cannot be regarded as the cause for the existence of the myth, but only as one of the reasons for its preservation. We shall hopefully glimpse something of the role of myth in Germanic societies in the course of my paper. Leaving Myth aside for the moment, I want to stress that ON prose material, including Heimskringla, shows a marked interest in the concrete manifestations of cult (which, for paganism as seen through Christian eyes at least, definitely includes magic) and belief. The Christian God and pagan gods alike are still seen to assist their followers in a tangible manner. The Christian Scandinavian worldview declares some of the more incredible feats ascribed to pagan gods or magicians as sjónhverfing (deception) caused by the Devil, i.e., within this limitation, still as real. The belief in the reality of the supernatural is indeed a fundamental aspect of the complex concept of truth which can be distilled from our sources ( $c$.
\end{abstract}


Buchholz 1980: ch. 5; Buchholz 1986). When, for example, King Olaf Tryggvason's attempts to christianize Norway (here: Rogaland) are to be opposed, the following happens:

Now when the king had finished speaking, then arose one of the farmers who was the most eloquent and had been chosen to answer King Óláf. But when he was about to speak he had such a fit of coughing and such difficulty with breathing that he could not utter a word and sat down again. Then another farmer arose with the intention not to fail in his reply, even though the first spokesman had not been so successful. But when he began he stammered so much that he did not get a word out. Then all those who listened fell to laughing, and he sat down. Then the third one got up to speak against King Óláf. But when he started to speak he was so hoarse and husky that no one understood what he said, so he sat down. Then no one of the farmers undertook to speak against the king. And as the farmers got no one to oppose the king, there was no resistance to him, and the end was that all agreed to the king's demands. Then all the people at the assembly were baptized before the king departed. (Heimskringla 1964: 197 [Óláfs s. Tryggvasonar, ch. 55])

In the same manner, Christian "magic" proves stronger than pagan sorcery:

\section{Chapter 78. Rauth the Strong and Thórir Hart Are Defeated by the King}

Rauth the Strong was the name of a farmer who lived at Gothey in the Sálptifjord. He was a man of great wealth and had many workers. He was a man who had much power. A great number of Finns followed him whenever he needed them. Rauth was much given to making sacrifices and was a great sorcerer. [...]

Chapter 79. Sorcery Prevents King Oláf's Fleet from Entering the Sálptifjord

King Óláf sailed north with his fleet along the land, baptizing all the people wherever he came. And when he arrived at the Sálptifjord in the north, he intended to enter it to find Rauth, but a furious squall and fierce gale swept out from the fjord, and the king lay there for a week, with the same tempestuous blast coming out of the fjord, whilst on the outside there was a favorable wind to sail north. Then the king sailed all the way north to Omth, where all the people accepted Christianity. Then the king reversed his course and steered south again. But when he approached the Sálptifjord from the north, squalls and spume again issued from it. The king lay there several nights while the same weather continued. Then the king spoke with Bishop Sigurth and inquired whether he knew what course to pursue. The bishop replied that he would try and see if God would lend him his might to overcome this fiendish power.

\section{Chapter 80. Bishop Sigurth Overcomes Rauth's Magic}

Bishop Sigurth put on all his vestments and went forward to the prow of the king's ship, had tapers lit and incense borne. He set up a crucifix on the 
stem of the ship, read the gospel and many other prayers, and sprinkled holy water all over the ship. Then he told them to take the tent coverings off and to row into the fjord. The king then had the order to go out to all the other ships to row behind his. And when they started rowing the Crane, she entered the fjord, and the rowers felt no wind blowing on them; and in the space left by its wake there was perfect calm, and the spoondrift receded on both sides, so that the mountains were hidden by it. Then one ship followed the other in that calm. Thus they proceeded all day, and then during the night, and shortly before daybreak arrived at Gothey. And when they approached Rauth's estate they saw his large dragon ship floating on the water near land. (Heimskringla 1964: 212 f. [Óláfs s. Tryggvasonar, chs. 78-80])

The history of the conversion of Norway, which is an important part of Snorri's work, has in fact decided aspects of a power struggle between the Christian God and the pagan demons (assisted by the Devil). While the king preaches Christianity (to the point of torturing and killing nonbelievers, if necessary), the local population and aristocracy want to maintain the old laws and the customs of their ancestors, especially with regard to sacrifices and the attendant cultic ceremonies with their drinking and merrymaking. The question was thus of the greatest public concern. Listen to Snorri's version of the course of a regional assembly at the time of the late loth century king Hakon the Good:

\section{Chapter 15. Asbjorn of Methalhús Opposes the King}

King Hákon came to the Frostathing Assembly, and a very large number of farmers attended it. When they met, King Hákon made a speech. He began by saying that it was his bidding and his request, addressed to freeholders and husbandmen alike, of high and low estate, and so to all the people, young men and old, rich and poor, women as well as men, that all should let themselves be baptized and believe in one God, Christ, the son of Mary, and stop all idolatry and heathen worship; that they should keep holy every seventh day, abstaining from work, and fast every seventh day.

But no sooner had the king proposed this to the people than there was a great muttering. The farmers complained that the king wanted to deprive them of their livelihood, that they could not cultivate the land in that fashion. But the working men and thralls thought they could not work unless they had food. They said, too, that it was a failing of King Hákon's, as it was of his father and their kinsmen, that they were stingy of food, even though they were generous in giving gold.

Asbjorn of Methalhús in Gaular Dale stood up to make answer to what the King had proposed, and spoke as follows.

"It was our thought, King Hákon," he said, "the time you had held our first assembly here in the Trondheim District and we had chosen you king and received from you the title to our ancestral possessions, that very heaven had come down to earth; but now we don't know what to think, whether we have regained our liberty or whether you are going to make us thralls again with the 
strange proposal that we should abandon the faith our fathers have had before us, and all our forefathers, first in the time when the dead were burned, and now in the age when the dead are buried. And they were better men than we, and yet this faith has served us very well. We have put so much trust in you that we have let you have your way about all the laws and statutes of our land. Now it is our will, and all the farmers are agreed on this, to obey the laws you have given us here at the Frostathing Assembly and to which we consented. We all want to follow you and to have you be our king so long as one of us farmers who are at the assembly now is alive, if you, sir king, will observe moderation and ask only that of us which we can give you and which is within reason.

"But if you mean to pursue this so high-handedly as to contend against us with force and compulsion, then all of us farmers have made up our minds to desert you and choose another leader, one who will help us freely to have the faith we wish to have. Now you, sir king, shall decide on one of these alternatives before the assembly disperses."

The farmers gave loud acclaim to this speech and said that it was this they wanted.

When silence was restored, Earl Sigurth made this answer: "It is the intention of King Hákon to agree with you farmers, and to let nothing stand between him and your friendship." The farmers said that it was their wish that the king should make sacrifice to procure for them good crops and peace, as his father had done. Thereupon the muttering ceased and they ended the assembly. [...]

\section{Chapter 17. Hákon Is Forced to Participate in the Sacrifice}

[...] Next day when people had seated themselves at the tables, the farmers thronged about the king, saying that now he must eat the horse meat [The horse was sacred to Óthin]. That, the king would not do under any condition. Then they asked him to drink the broth from it. He refused to do that. Then they asked him to eat the drippings from it. He would not do that, either, and they came near to making an attack on him. Earl Sigurth said he would help them come to an agreement, asking them to cease their tumult; and he asked the king to gape with his mouth over the handle of the kettle on which the smoke of the broth from the horse meat had settled, so that the handle was greasy from it. Then the king went up to it and put a linen cloth over the handle and gaped with his mouth over it. Then he went back to his high-seat, and neither party was satisfied with that. (Heimskringla 1964: 108-111. [Hákonar s. góða, chs. 15-17])

Indeed some smelly compromise. This was of course no lasting solution. That was rather to come through Olaf Tryggvason's brutality (supported by near - miracles) and finally through Olaf the Saint, in a less violent fashion (with more miracles).

We have already seen that, at least in Snorri's 13th century view, pagan groups were interested in maintaining the beliefs of their ancestors as an established way of life, and in having the king sacrifice for a good harvest 
and for peace (til árs ok friðar). Firstly, a strong local tradition, and secondly, apparently a belief in aspects of sacral kingship are obviously significant for the problem which is the topic of my paper: identity, more specifically, group identity. Thus, one of our medieval sources clearly shows the importance of the concept and encourages us to follow it up in other texts or even other kinds of documents, pictorial and archaeological. Any number of theoretical and practical questions now present themselves. How can we arrive at religious foundations of group identity in the case of archaeological material? Are there limitations of the concept caused by polytheism or by social stratification? Such questions can, for Gmc. paganism, be answered only partially (if at all) at present. The source material is too scanty, too fragmentary, or even too ambiguous. Regional or group cults can still be made the topic of interdisciplinary research projects with some chance of success, provided the goals are clearly defined, and the project has the necessary financial and organisational backing (Buchholz 1972b) ${ }^{\mathrm{x}}$. Even in the field of Germanic religion, the number of publications is very high and difficult to survey. My own Bibliographie zur Alteuropäischen Religionsgeschichte 1954-64 contains some 5,000 publications (Buchholz 1967), my successor's five-year sequel (1965-69) already has 10,000 (Ahrendts 1974). My decision to group entries mainly according to historical and geographical criteria met with unanimous approval by the ca. 40 reviewers. It is certainly helpful to have a bibliography listing e.g. together archaeological and place name research on the same cult place, and placing it in a historical and regional context. Myths are, of course, not so easily accommodated in such a system; in most cases, they had to be dealt with under the literary sources that contain them. This practical problem already indicates that a correlation of a specific ON myth with a specific Scandinavian or German cult place is highly problematical. There is no doubt in principle that myths could be recited as part of cultic proceedings. But the nature of our source material makes it rather difficult to find concrete instances of this. It

${ }^{1}$ My own project was discontinued just before it could publish the first results. The "Sonderforschungsbereich 17, Skandinavien- und Ostseeraumforschung", a (now defunct) misconstruction with projects from archaeology, modern literature and, particularly, the economic sciences, predictably discovered that cooperation between some projects was not possible. The "solution" was to get rid of some smaller projects. I mention this as a solemn warning against hasty and ill-considered construction of research entities under the flag of a multi-disciplinary approach. At least, there must be safeguards against majority decisions affecting subjects about which that majority knows nothing. This simply follows from generally accepted principles of science and scholarship. 
remains nevertheless one of the most challenging research problems in our field. The re-enactment of origin legends at sanctuaries, mentioned in my summary, may well have taken place, but can only be inferred indirectly from written sources and not at all from the archaeologocial finds (which obviously do not contain myths or legends). Religious foundations of group identity can, in the Gmc. field in any case, only be proven with the help of written sources, and at best further confirmed or illustrated by archaeological and pictorial material ${ }^{2}$. Archaeological and place name research, on the other hand, has yielded a number of cult places. For the purposes of the present paper, both Gmc. "cult in life" and "cult in liter ature" are obviously of interest. For practical reasons, it is best just to discuss or mention the sources we have, and not to try to systematize too much at this stage in the research situation (cf. Buchholz 1968a; Buchholz 1972a; Buchholz 1975). However, the time at my disposal does not permit me to quote or discuss all or even the most important sources, and I must refer you to the handbooks (Jan de Vries is still utterly indispensable). What follows is thus nothing more than a sequence of data which I personally find decisive or promising for further research in connection with the identity problem.

One of the earliest attestations of what must be Gmc. mythical and/or cult poetry is to be found in Tacitus Germania ch. $2^{3}$ :

In their ancient songs, their only form of recorded history, the Germans celebrate the earth-born god, Tuisto. They assign to him a son, Mannus, the author of their race, and to Mannus three sons, their founders, after whom the people nearest the Ocean are named Ingaevones, those of the centre Herminones, the remainder Istaevones. The remote past invites guesswork, and so some $(x)$ record more sons of the god and more national names, such as Marsi, Gambrivii, Suebi and Vandilici, and maintain that $(x)$ these names are indeed genuine and ancient.

At least some Gmc. tribes thus traced their origin to three generations of gods. The primeval being, Tuisto, fittingly is androgynous (according to the most probable etymology); his son is Mannus, "the human being", two of whose three sons can be linked to later Scandinavian and West

2 The pictorial monuments (e.g. the Gotland picture stones and the gold bracteates) can yield information not contained in the written ON sources, but the interpretation of many of them is nevertheless impossible without the help of written sources. See note 5 .

3 The translations from Tacitus follow the Penguin translation by H. Mattingly (Tacitus 1971). I have, however, had to correct an inaccuracy (marked $x$ ). The best commented ed. is Tacitus 1967. 
Germanic divine or royal names (Ing, Yngvi, Ynglingar; Irmin). The name of the third group, Istaevones (var. Istraeones, Plinius) has not yet been convincingly explained. Almost more interesting than this genealogy is Tacitus' remark that there were more "genuine and ancient" names of gods and (corresponding) tribes. We must conclude that other tribes had traditions celebrating other sons of Mannus, which are, very much to our regret, not mentioned by Tacitus. It is obvious in my view that such differing genealogies existed. Further proof of this is the number of actually incompatible creation myths preserved in $O N$ tradition. And if still further proof was required, we actually have two completely different genealogies, one from Snorri's Edda (SnE 14: Búri - Burr - Óðinn, Vili, Vé), the other from Guta saga, an ON (Old Gutnic) historical account of the isle of Gotland (Pielvar - Hafdi - Guti, Graipr, Gunnfjaun). The three sons in the third generation always alliterate. Obviously, there were considerable variations in the myths told and, as we shall see, also in the cults performed in the vast areas of Scandinavia, Denmark and Northern Germany. But that myths such as those mentioned were fundamentally linked to group identity is beyond doubt. Moving on now for a while to the question of Germanic cult practices, we can summarily state that, apart from private and family cults (which did exist, but which we cannot discuss here), public cult took place at certain fixed times of the year (connected with the agricultural calendar) or on special occasions (e.g. connected with famine or war), and at specific sanctuaries. Again according to Guta saga, there seem to have existed different "ranks" of cult places: for the village, the region, and the whole island. Human sacrifices were only performed at the larger sanctuaries, which statement is confirmed by archaeology and ON literature. Human sacrifices thus did exist, but were gener ally not performed on a large scale. Animal sacrifices were far more frequent. Agricultural products and implements, weapons and objects of value were also sacrificed. We have, for instance, a Celtic sacrificial kettle (with scenes of religious significance, e.g. a human sacrifice, depicted on it), which was itself sacrificed in a Danish bog (Gundestrup), or wagons and wheels (Dejbjerg, Rappendam; cf. also the Bronze Age sun chariot of Trundholm), also from bogs. The Dejbjerg wagon even had a seat for a priest or a sacral image. We can correlate such and other finds with an agricultural milieu and its appropriate rites and myths - cf. the ON traditions about the Vanir or the god Freyr, especially his "tour" through Sweden (Schröder 1929: 24-27)", accompanied by his "wife",

${ }^{4}$ Gunnars Páttr Helmings. 
which probably derives from a hieros gamos in promotion of agricultural fertility. Tacitus (Germ. 40) describes cultic practices in this connection as follows:

After them come the Reudigni, Aviones, Anglii, Varini, Eudoses, Suarini and Nuitones behind their ramparts of rivers and woods. There is nothing particularly noteworthy about these people in detail, but they are distinguished by a common worship of Nerthus, or Mother Earth. They believe that she interests herself in human affairs and rides through their peoples. In an island in the Ocean stands a sacred grove, and in the grove stands a car draped with a cloth which none but the priest may touch. The priest can feel the presence of the goddess in this holy of holies, and attends her, in deepest reverence, as her car is drawn by kine. Then follow days of rejoicing and merry-making in every place that she honours with her advent and stay. No one goes to war, no one takes up arms; every object of iron is locked away; then, and then only, are peace and quiet known and prized, until the goddess is again restored to her temple by the priest, when she has had her fill of the society of men. After that, the car, the cloth and, believe it if you will, the goddess herself are washed clean in a secluded lake. This service is performed by slaves who are immediately afterwards drowned in the lake. Thus mystery begets terror and a pious reluctance to ask what that sight can be which is allowed only to dying eyes.

The name Nerthus is related to ON NjQrðr, a male god and member of the vanir together with Freyr. "Mother Earth" indeed seems to have received human sacrifices, as a bog corpse was discovered together with the wagons of Rappendam. The danish archaeologist P. V. Glob links the majority of the considerable number of bog corpses ("Moorleichen") with the Nerthus cult, which is perhaps somewhat simplistic, since according to Tacitus (Germ. 12) and to the finds, there were probably several reasons for the death penalty or for submerging a delinquent or a human sacrifice (which two categories can, but need not coincide) in a fen. The whole category of bog corpses (including "parts" like heads or limbs found in isolation) merits full treatment in book form and does not lend itself to summary in a few sentences.

We can conclude from what Tacitus describes, I think, that gods and/or goddesses were driven in procession round their region, in order to promote fertility and peace (Tac. clausum omne ferrum), cf. the ON sacrificial formula til árs ok friðar, usually addressed to Freyr. Such divine beings had a decided agricultural aspect and also promoted peace as a precondition for the proper cultivation of fields.

A great number of Scandinavian and Germanic place names must refer to pagan cult places. In particular, there are the so-called theophorous 
place names (part 1 of the name denotes a god, part 2 either a certain kind of sanctuary, or it is a "nature name"). Unfortunately, the relative and absolute chronology of Scandinavian place names has not yet been established with sufficient reliability (Vries 1956-57/2; Dalberg et al. 1984). It is clear, however, that there were different designations for sanctuaries, either of a general nature (vé) or referring to a piece of land or (important!) water (akr, vin, land, vangr, heimr, berg; sær, fors, bekkr, mosi), or to an artificial structure (haugr "grave mound" - also "hill", horgr "stone heap with primitive sculpture", hjallr "elevated platform", stafgarðr "fence incorporating or enclosing posts"). Most sanctuaries were obviously also dedicated to specific gods, at least according to the place names. Cult places seem to have possessed a "priest" or priests responsible for the sacrifices, according to some Runic inscriptions (and designations like OHG harugari, OE heargweard, ON goði, hofgoði): Nordhuglen, $400 \mathrm{AD}$ ek gudija ungandiR "I the priest immune against sorcery", Rök, 8th c. uiauari "protector of the sanctuary", Snoldelev, 9th c., pulaR a Salhaugum "(of the) speaker at Sal-hills - both ON pulr and haugr have strong religious connotations, to say the least -, and others (Vries 195657/1: 397-406).

In summary, then, there were different ranks and different kinds of sanctuaries, with different structures, and dedicated to different gods. Some seem to have had the services of a person in charge of ceremonies. This situation, as it is according to place names and written sources, obviously cries out for assistance by other disciplines, especially archaeology. Place name research can, in its turn, help archaeology by indicating "where to dig", albeit often too vaguely. ON literature can give hints as to the nature of structures or even priests' or magicians' insignia or accessories (staff; girdle; magic pouch! ecstasy-inducing drugs!). Archaeology has been able to demonstrate quite impressively the kind of sacrifices and the manner of sacrificing at a number of sanctuaries (Jankuhn 1970). Obviously, it can not give the name(s) of the god(s) to whom the offerings were made. It can at most approach the problem indirectly by informing us about the above details and the society which sacrificed, e.g. a group of peaceful peasants (Käringsjön) or a warrior aristocracy (Thorsberg, Vimose, Nydam, Ejsbøl, Skedemosse). It must be emphasized that, as in the Romano-Gaulish case, a number of different gods could be venerated in the same sanctuary, perhaps in a historical sequence, but probably also at the same time. A good example of that situation is provided by what is in fact the most exciting and important excavation of a Germanic sanctuary yet: that of the Hermunduric fen and lake sanctuary of Oberdorla in Thuringia, 
which was used from the pre-Roman Iron Age to the 4 th century AD, i.e. for more than half a millennium. More than twenty idols, both male and female, were found here in differing contexts, with differing attributes and sacrifices including humans. One of the many interesting find categories is the great number of wooden sticks 60 to $80 \mathrm{cms}$ long; they may have been used in connection with the sacrifices for oracular purposes (cf. ON fella blótspán "to let fall the sacrificial pieces of wood"), to find out if the god accepted the sacrifice and granted the wish with which it was most probably made. Some of the idols at other cult places were still put in or near a heap of stones (Broddenbjærg fen). Cf. the following Eddic passage (Hyndluljóð lo, transl. P. Buchholz):
Horg hann mér gerði, nú er griót pat rauð hann í nýio æ trúơi Óttarr

\author{
hlaðinn steinom, \\ at gleri orðit; \\ nauta blóði, \\ á ásynior.
}

"He made me (sc. Freyja, a Vanir goddess) a horgr constructed of stones, now this rock has become glass; he reddened it in fresh cattle blood; Ottarr always honoured the goddesses".

The glass-like impression of the sacrificial "altar" can be explained by the effect of fires in connection with the blood. A number of Gmc. sanctuaries contain fire places where e.g. probably sacrificial meals were cooked (but also connected with throwing firebrands at something!). The Guta saga calls the sacrificial participants supnautar "cooking companions".

We are now approaching the most difficult questions: Which gods were venerated, which myths were recited at the sanctuaries? As already indicated, the overwhelming majority of archaeological sources do not, and cannot, reveal this. Let us quote from Tacitus (Germ. 39) for the last time:

The oldest and noblest of the Suebi, so it is said, are the Semnones, and the justice of this claim is confirmed by a religious rite. At a set time all the peoples of this blood gather, in their embassies, in a wood hallowed by the auguries of their ancestors and the awe of ages. The sacrifice in public of a human victim marks the grisly opening of their savage ritual. In another way, too, reverence is paid to the grove. No one may enter it unless he is bound with a cord. By this he acknowledges his own inferiority and the power of the deity. Should he chance to fall, he must not get up on his feet again. He must roll out over the ground. All this complex of superstition reflects the belief that in that grove the nation had its birth, and that there dwells the god who rules over all, while the rest of the world is subject to his sway. Weight is lent to this belief by the prosperity of the Semnones. 
Germanic belief in a divine ancestor as origin of the tribe, binding it in a common identity, can hardly be expressed more explicitly. The supreme god (whom we need not identify with members of the later ON pantheon!) is placated with a human sacrifice - according to one theory, in a reenactment of the creation of the world from the dismembered primeval giant Ymir. We do not however know anything about the Semnonic ideas of creation. The detail about the specific mode of entrance into the grove, in contrast, does show some affinity with later Nordic tradition: Helgi is killed by the hero Dagr with Odin's spear in Fioturlundr ("grove of fetters") according to HHund II (prose after v. 24. Kuhn [Edda] 1962: 157). That multi-faceted god, Óðinn, had a definite penchant for human sacrifices, usually performed by hanging and/or stabbing. A number of ON legendary heroes were assisted by the god, but often abandoned by him in the end. Several Gmc. royal families traced their origins to Woden/Óðinn. The warrior aristocracies seem to have had a special relationship with this god who was not only a fountain of wisdom, but also extremely skilled in battle magic. As I showed elsewhere (Buchholz $1968 \mathrm{~b}$ ), it is even justified to consider him a divine shaman. These aspects are, at least typologically, extremely old. The Gmc. aristocracy may, from its origins in the late Iron Age, have derived a feeling of corporate identity from divine ancestors and helpers that exhibited such traits as found in the later image of Óðinn. This is most certainly only a hypothesis, but I think plausible. Whether it was this god to whom huge numbers of weapons were sacrificed in migration - age fen sanctuaries, we cannot know for sure. The god does indeed have some subterranean and aquatic aspects. The later connection of Odin and the warrior aristocracy, however, is a fact. Place names connected with Óðinn show that the sanctuaries of this god must have played a role in the formation of the state of Denmark and its main provinces. This remarkable result of place name research fits in very well with my "Wodanistic" aristocracy. The German medievalist Karl Hauck, extensively using data from my dissertation (Buchholz 1968b), has succeeded in demonstrating clear depictions of Óðinn and his shamanistic abilities (including healing and battle magic) on migration-age gold bracteates ${ }^{5}$. These bracteates were certainly used as protective amulets, and most probably manufactured in or near the Danish sanctuaries of Odin (Hauck 1980) ${ }^{6}$. The followers of wealthy and powerful chieftains are a likely circle of recipients for such amulets. As a

${ }^{5}$ Cf. Hauck 1970 and some 20 articles (a number of them in Frühmittelalterliche Studien).

${ }^{6}$ Hauck 1980 is fundamental also in respect of Gmc. identity. 
few pictorial monuments show, these holy pieces could even be used as a kind of entry permit into the other world (Hauck 1980: $574 \mathrm{f}$.).

The spectacular progress of research on the god Óðinn in connection with the gold bracteates and with shamanism has indeed helped to shed light on the religious foundations of aristocratic group identity. The wealth of data from pictorial and written documents connected with Odin and shamanism can, in my view, provide a good foundation for sectoral progress in interpreting archaeological finds previously perhaps not suspected of being linked to religion at all. That the institution of "comitatus", "Gefolgschaft" (organized "following" of a chieftain, dependent on him for a living, giving warrior services in return) was of paramount importance in Gmc. society has again been convincingly demonstrated by the most recent book on Gmc. social structure (Steuer 1982).

\section{References Cited}

\section{Ahrendts, Jürgen}

1974 Bibliographie zur alteuropäischen Religionsgeschichte. 2. Bd. 1965-1969. Berlin: Walter de Gruyter. (Arbeiten zur Frühmittelalterforschung, 5)

Buchholz, $\mathbb{P}$.

1967 Bibliographie zur alteuropäischen Religionsgeschichte, 1954-1964. Berlin: WaIter de Gruyter. (Arbeiten zur Frühmittelalterforschung, 2)

1968a Perspectives for Historical Research in Germanic Religion. History of Religions 8: 111-138.

1968b Schamanistische Züge in der altisländischen Überlieferung. Münster: Unpublished diss.

1972a Im Himmel wie auf Erden. Gedanken zu Heiligtum und Kultprowinz in der frühgeschichtlichen Religion Skandinaviens. Acta Germanica 7: 1-17.

1972b The Religious Geography of Pagan Scandinavia. A New Research Project. Mediaeval Scandinavia 5: 89-91.

1975 Forschungsprobleme germanisher Religionsgeschichte. Christiana Albertina: 19-29.

1980 Vorzeitkunde. Mündliches Erzählen und Überliefen im mittelalterlichen Skandinavien nach dem Zeugnis von Fornaldarsaga und eddischer Dichtung. Neumünster: Wachholtz. (Skandinavistische Studien, 13)

1986 The True Runes of the First Word. Medieval Scandinavian Views on Reliability and Truth of Oral Traditions. Mankind Quarterly 27: 201-206.

1991 Ancient Lore: Oral Tradition in Medieval Scandinavia. In: Perspectives on Indo-European Language, Culture and Religion. Studies in Honour of Edgar C. E. Polomé; vol. 2; pp. 502-510. McLean, VA: Institute for the Study of Man. (Journal of Indo-European Studies. Monograph, 9)

Dalberg, V. et al. (eds.)

1984 Bebyggelsers og bebyggelsenavnes alder. Uppsala: NORNA-Förlaget. (NORNArapporter, 26) 
Hauck, Karl

1970 Goldbrakteaten aus Sievern. München: Fink. (Münstersche MittelalterSchriften, 1)

1980 Gemeinschaftsstiftende Kulte der Seegermanen. In: Karl Hauck (Hrsg.), Frühmittelalterliche Studien 14; pp. 463-617. Berlin: Walter de Gruyter.

Heimskringla

1964 Heimskringla. Transl. by Lee M. Hollander. Austin: University of Texas Press.

Jankuhn, Herbert (Hrsg.)

1970 Vorgeschichtliche Heiligtümer und Opferplätze in Mittel- und Nordeuropa. Göttingen: Vandenhoeck \& Ruprecht.

Kuhn, Hans (Hrsg.)

1962 Edda. Die Lieder des Codex Regius. Nebst verwandten Denkmälern. 3. umgearb. Auf. Heidelberg: Winter.

Schröder, Franz Rolf

1929 Die Germanen. 2. Aufl. Tübingen: J. C. B. Mohr (Paul Siebeck). (Religionsgeschichtliches Lesebuch, 12)

Steuer, Heiko

1982 Frühgeschichtliche Sozialstrukturen in Mitteleuropa. Göttingen: Vandenhoeck \& Ruprecht. (Abhandlungen der Akademie der Wissenschaften in Göttingen. Phil.-Hist. Klasse, 3/128)

[Tacitus]

1967 Die Germania des Tacitus. 3. erw. Aufl. Erläutert von Rudolf Much. Unter Mitarbeit von Herbert Jankuhn hrsg. von Wolfgang Lange. Heidelberg: Winter.

Tacitus

1971 Agricola and the Germania. Transl. by Hugh Mattingly. New York, NY: Viking Penguin.

Vries, Jan de

1956-57 Altgermanische Religionsgeschichte; 2 vols. Berlin: Walter de Gruyter. (Grundriss der germanischen Philologie, 12/1-2) 